\title{
3
}

\section{The Gibbet in the Landscape: Locating the Criminal Corpse in Mid-Eighteenth-Century England}

\author{
Zoe Dyndor
}

In the late 1740s a group of smugglers known as the Hawkhurst gang committed a number of violent crimes that included several brutal murders. At least 75 of the gang were subsequently hung or transported for smuggling, robbery and murder. Of those in receipt of the death sentence, 14 were subjected to the further punishment of hanging in chains (or gibbeting), thereby inflicting further ignominy on the offenders. ${ }^{1}$ Hanging in chains was usually reserved for murderers, and occasionally mail robbers. However, between 1747 and 1750 members of the Hawkhurst gang were also gibbeted for crimes including smuggling and robbery. Gibbeting was an infrequently used punishment, but the violent circumstances of the Hawkhurst gang's crimes coupled with the authorities' desire to punish smugglers on the south coast led to the large number of gibbetings, and consequently a peak in the use of the punishment in the 1740s. These gibbetings reflected the increasingly severe measures taken to eradicate the crime of smuggling. They were temporally and spatially specific, reflecting the nature of the crimes and the circumstances that led to the hanging in chains. This study provides an insight into the extreme use of a particular punishment, showing that judicial penalties were adapted to fit the circumstances of the crimes and reflect how the offences were perceived.

Hanging a body in chains was a post-execution punishment used to subject further humiliation and ignominy on criminals who were to be made an example of, or were deemed to have committed especially heinous crimes. The Murder Act of 1752 stipulated that criminals convicted of murder should not be buried, but instead hung in chains or anatomised and dissected. The practice of hanging in chains, however, pre-dates this Act by hundreds of years, with bodies gibbeted in the 
early-modern and medieval periods. More bodies were gibbeted on the eve of the passage of the Murder Act than in any of the decades that followed, though not all of those gibbeted were convicted of murder. ${ }^{2}$ The location of many of these gibbets has been recorded in maps, documents and in folklore. The purpose of this chapter is to examine the ways in which the authorities used one of the most severe punishments available to them in the eighteenth century, and the logic and rationale behind their decision to use the punishment.

This will be achieved through a case study of the Hawkhurst gang and the locations in which they were hung in chains. Gibbeting was a costly procedure that involved the production of a gibbet cage and post that were designed to be viewed by as many people as possible. The spectacle of hanging the body in chains was in a sense an extension of the hanging ritual: public, exemplary and a deterrent. As well as inflicting further punishment and humiliation on the body, the practice allowed for even greater numbers to witness the spectacle. As Steve Poole showed in Chapter 2, the selection of the location of crime-scene hangings was purposeful and integral to the hanging ritual. Likewise, the location of the gibbet was as significant an aspect of the punishment as was the cage and post itself. The gibbetings of the Hawkhurst gang suggest that there were many considerations that led to the selection of gibbet locations. This chapter will assess how far the considerations used in choosing the gibbet sites of the smugglers in the 1740s were used more widely across the eighteenth century in deciding where exactly criminals should be hung in chains.

This chapter will focus on the three geographical areas in which the smugglers were hung in chains: London, West Sussex in the area surrounding Chichester and the East Sussex/Kent border near Hawkhurst. Gibbet locations were selected for different reasons in each of the locations. It will be considered why there were these differences and how the choices related to the criminals, the crimes committed and the places themselves. It will be argued that while the gibbeting of criminals in London was in some ways unique, the differences in the crimes committed by those gibbeted in West and East Sussex were different and this was reflected in the locations at which the criminals were hung in chains. To begin with the chapter will briefly set out who the smugglers were and the process of gibbeting, before assessing the typology and landscape of the gibbets in London, West Sussex and East Sussex. It will finally consider how far the reasons used for selecting the gibbet sites of the Hawkhurst gang were applied more widely. 


\section{The Smugglers}

All of the men considered in this chapter were members of the Hawkhust Gang, a notorious band of smugglers that operated on the Sussex and Kent coast. The prosecution of these smugglers for a series of crimes, including murder and robbery, led to a peak in the use of hanging in chains in the late 1740 s and early 1750s. This section will examine the offenders who were tried for smuggling from the Kent/Sussex area between 1747 and 1750. It has been argued elsewhere that an escalation of violence between smugglers and the authorities resulted in the increasingly harsh punishment of smugglers that normalised hanging in chains for this particular group of offenders. ${ }^{3}$ What is of interest in this chapter is not the crimes or the criminals themselves - about which much has already been written - but how these relate to the locations in which their bodies were subsequently gibbeted.

These men were part of a larger group of smugglers hanged between 1747 and 1751 (see Tables 3.1 and 3.2). As well as smuggling, the offenders were convicted of murder (several brutal murders were committed by the smugglers), robbing the customs house at Poole and a series of property crimes. Nicholas Rogers has demonstrated that at least 35 smugglers from the south coast were hanged in the years 1749-50 alone. ${ }^{4}$ In Sussex and Kent a total of 50 smugglers were sentenced to be hanged or transported in the years 1747 to 1752 . The majority of these were convicted at the Old Bailey, with 18 men convicted of smuggling and 3 of robbing the customs house at Poole; 6 smugglers were sentenced to hang in Kent while 14 were tried in Sussex.

Only one of the convicted smugglers was pardoned (Richard Glover), one was acquitted (Thomas Lillywhite), and three turned king's evidence to avoid the gallows. ${ }^{5}$ The high number of convictions of the smugglers provides some context for the high number of bodies hung in chains: along with high numbers of death sentences went unusually large numbers of post-mortem punishments. It is notable that there were 23 smugglers from East Anglia sentenced to death in this period, however none of them received a post-mortem punishment. ${ }^{6}$ This was not due to the fact that hanging in chains was not utilised in East Anglia - offenders certainly were hung in chains in the area; but the practice was not used as a punishment for smugglers. This suggests that the relationship between the smugglers, their crimes and the authorities was unique in Sussex and Kent.

Of the 16 smugglers hung in chains in the late 1740 s and early 1750 s, seven were convicted at the Old Bailey, eight in Sussex and one in Kent. 
Table 3.1 Numbers of smugglers convicted at the Old Bailey, Sussex and Kent Assizes, and the punishments they received, 1747-51

\begin{tabular}{lccccccc}
\hline Year & Convicted & \multicolumn{5}{c}{ Punishment } & \multirow{2}{*}{ Hung in chains } \\
\cline { 3 - 6 } & & Transportation & Hanging & Pardoned & Died & Total & \\
\hline 1747 & 5 & - & 5 & - & - & 5 & 3 \\
1748 & 11 & - & 11 & - & - & 11 & 2 \\
1749 & 32 & 5 & 24 & 1 & 2 & 32 & 11 \\
1750 & 1 & - & 1 & - & - & 1 & - \\
1751 & - & - & - & - & - & - & - \\
1752 & 1 & - & 1 & - & - & 1 & - \\
Total & 50 & 5 & 42 & 1 & 2 & 50 & 16 \\
\hline
\end{tabular}

Sources: TNA, T 64/262, ASSI 23/6, ASSI 31/2; Old Bailey Online.

Table 3.2 Smugglers hung in chains, 1747-9

\begin{tabular}{|c|c|c|c|c|}
\hline Area & Name & Crime & Gibbet location & Date \\
\hline \multirow[t]{4}{*}{ London } & John Cook & Smuggling & Shepherd's Bush & 29.07.1747 \\
\hline & Richard Ashcroft & Smuggling & Shepherd's Bush & 29.07.1747 \\
\hline & Samuel Austin & Smuggling & Shepherd's Bush & 21.12 .1747 \\
\hline & Arthur Gray & Smuggling & Stamford Hill & 11.05 .1748 \\
\hline \multirow[t]{7}{*}{ West Sussex } & Benjamin Tapner & Murder & $\begin{array}{l}\text { Rooks Hill, } \\
\text { Chichester }\end{array}$ & 19.01.1749 \\
\hline & William Carter & Murder & $\begin{array}{l}\text { Portsmouth Road, } \\
\text { Rake }\end{array}$ & 19.01.1749 \\
\hline & John Cobby & Murder & Selsey Isle & 19.01 .1749 \\
\hline & John Hammond & Murder & Selsey Isle & 19.01.1749 \\
\hline & John Mills & Murder & Slindon Common & 20.03.1749 \\
\hline & Henry Sheerman & Murder & Rake & 21.03.1749 \\
\hline & William Fairall & $\begin{array}{l}\text { Robbing } \\
\text { Customs House }\end{array}$ & Horsmonden & 26.04.1749 \\
\hline \multirow[t]{5}{*}{ East Sussex } & William Hartnup & Smuggling & Goudhurst Gore & 14.04 .1748 \\
\hline & Thomas Kingsmill & $\begin{array}{l}\text { Robbing } \\
\text { Customs House }\end{array}$ & Goudhurst Gore & 26.04.1749 \\
\hline & Richard Mapesden & Smuggling & Lamberhurst & 04.08 .1749 \\
\hline & Edmund Richards & Murder & Hambrook Common & 09.08 .1749 \\
\hline & George Chapman & Murder & Hurst Common & 19.08.1749 \\
\hline
\end{tabular}

Sources: TNA, T 64/262; ASSI 23/6, ASSI 31/2; West Sussex Record Office (WSRO), Goodwood MSS 154; Old Bailey Online.

One other man, William Jackson, was sentenced to hang in chains but died before execution. He was convicted of murder along with six others at a Special Assize in Chichester. ${ }^{7}$ This had been carried out to try those who had participated in the torture and murder of William Galley and Daniel Chater. The Duke of Richmond had petitioned for the Special 
Assize to be held at Chichester, local to the murders, due to the severity of the crimes. ${ }^{8}$ As a result of his death, Jackson's body was thrown in a hole where the gallows was located, along with Richard Mills, senior, and Richard Mills, junior, two of his accomplices. Mills junior and senior, however, were not sentenced to hang in chains as they were not considered to be principals in the murder. Incidentally, the sentence of hanging in chains was cited as the reason for Jackson's death in contemporary accounts. According to the pseudonymous writer, 'Gentleman at Chichester', upon hearing he was to be hung in chains, Jackson was so overcome he dropped down dead. ${ }^{9}$ Jackson had been ill throughout the trial and did indeed die prior to his execution. ${ }^{10}$ Though the account that his death was a consequence of his sentencing to the post-mortem punishment is implausible, it does suggest the way in which this punishment was viewed by those in receipt of it and how it was portrayed by those by whom it was administered. The gibbet was designed as a fate worse than death and this is how it was presented.

\section{The Technology of the Gibbet}

The process of hanging in chains involved hanging an executed body in an iron cage on a high gibbet post. This was a costly, time consuming process and the utilisation of this form of punishment is suggestive of the lengths that the authorities were willing to go in the quest to make an example of this group of smugglers. After execution, a body would 'hang for the usual time' (usually thirty minutes to an hour) before being cut down to be prepared for its post-mortem punishment. The body was then encased in an iron cage that had been made specially. The cage would then be hung from a gibbet post, usually between twenty and thirty feet high, and strengthened with iron. Nails would often be placed into the post to deter people from climbing up and taking the body. Sarah Tarlow has shown that sets of irons were usually made on a bespoke basis - each individual was measured up for their chains prior to execution by the local blacksmith. Sets of chains varied considerably in style, as often the smith would have had no experience or precedence for making them. Some were more elaborate than others as designs varied from a simple chain round the whole body to iron bands moulded around the arms and legs. Often they were adjustable. The joint between the post and the gibbet was often constructed so that the body could turn around in the wind. There is no surviving evidence as to what the gibbets or cages of the Hawkhurst gang were like, indeed few gibbet cages survive. ${ }^{11}$ 
The workmanship that went into the gibbeting is shown in the sheriff's cravings, a source that details the expenses the county sheriff claimed from the treasury in organising the execution and hanging in chains of offenders. The sheriff's cravings for Sussex in 1749 detail the costs of the execution and gibbeting of several of the Hawkhurst gang. Expenses ranged from paying attendants at the execution, to transportation to the place of gibbeting, to irons for the bodies. The cravings show that the carpenter Richard Goodman charged $£ 17$ 14s for three gibbet posts for Richard Mills, Henry Sheerman and Edmund Richards. Goodman filed several bills of expense, including fixing the gallows and providing materials. The gibbet for George Chapman was not made at Hurst Green as the carpenter 'did not care to make gibbets for smugglers'. ${ }^{12}$ This indicates that there were those who did not believe in hanging smugglers in chains. As a result the gibbet post was made in Lewes at a cost of $£ 515 \mathrm{~s} 6 \mathrm{~d}$. It was then transported to Hurst Green from Lewes at the cost of $£ 3$ 3s. Additional expense was thus incurred to find a carpenter who would make the gibbet post. The cages for the smugglers ranged in cost from $£ 4$ to $£ 6$. Providing the iron to strengthen the post was even more costly: James Beeding junior was paid $£ 8$ 9s for ironwork for the chains, cage and gibbet post of John Mills. William Fairall and Thomas Kingsmill were both executed at Tyburn and transported to Kent to be hung in chains. The cost of gibbeting these men was $£ 24$ s each, including posts, 'strong iron riveting to prevent smugglers from cutting them down', chains and transporting the bodies. ${ }^{13}$

Hanging a body in chains was thus a costly procedure. This goes some way to explaining why the punishment was administered less frequently than dissection in the years after the introduction of the Murder Act in 1752 - over 80 per cent of the offenders sentenced under the Murder Act between 1752 and 1832 were sent to be dissected and anatomised rather than hung in chains. ${ }^{14}$ Gibbets were expensive structures that would need to produce the largest possible impact to make the punishment worthwhile. Given that the authorities went to such effort and expense to make the gibbets, the choice of a suitable gibbet location was essential in ensuring that the bodies would be seen by as many people as possible. Gibbets were designed to have a powerful visual and sensory impact: their height would make them visible from great distances and a large proportion of the body itself would be seen in the iron cage. The body in the gibbet cage swivelling round on a pivot attached to the post would have produced sounds and smells that meant that even if the gibbet could not be seen, its presence would be known. Reinforcing the gibbet with iron and adding nails to prevent 
people climbing up the post to steal the body suggests that these structures were made to last. Given that there was no time limit on how long the gibbet would remain standing, gibbets were in many ways semi-permanent features of the landscape and a long-term symbol of the spectacle of punishment. Using this punishment in spite of the cost and workmanship that went into the production of the gibbet is indicative of the lengths the authorities were willing to go to in order to deter the crimes committed by smugglers, and make a lasting example of this particular group of men.

\section{Typography of Hanging in Chains Locations}

There were a variety of reasons for choosing where gibbets would be located. This section will consider the locations at which the bodies of the smugglers were hung in chains and how these can be categorised. It has been suggested that gibbets were located at parish boundaries, as Nicola Whyte has argued in her examination of gibbets in Norfolk in the late eighteenth century. She has shown that there was a spatial pattern in which gibbets were placed on common land near parish boundaries. ${ }^{15}$ However, this pattern has yet to be found elsewhere. In fact, in most counties spaces as close to the crime location as was convenient were chosen. ${ }^{16}$ The positioning of the gibbets of this group of smugglers has shown that there was a more extensive range of gibbet location typologies. There were numerous reasons why gibbet locations were selected: proximity to the location of the crime, the place where the victim came from, the place where the criminal came from, on a major travel route, a prominent location where large numbers could view the gibbet, a place where a specific audience would view the gibbet, and a space where gibbeting was common. Finding a suitable location for the gibbet was thus important and could be a subject of some debate. In 1752, for example, there was some controversy as to where the body of John Swan should be hung in chains. Swan had been hanged for murder in Walthamstow and his body was directed to be hung in chains on the same gibbet. However, it was decided by $\mathrm{Mr}$ Justice Wright that this location was not suitable as it was 'in full view of some Gentlemen's houses on the Forest' and it should be 'left to the Gentlemen of Walthamstow to consult with the under-sheriff, and fix a proper place to erect a gibbet on'. The location eventually decided upon was Buckets Hill, near the Bald Faced Stag as being both a suitable location for a gibbet and one that was associated with Swan. ${ }^{17}$ This location did not prove satisfactory as some gentlemen from the area complained, 
so the body was later moved to Hagen Lane in Walthamstow near to where the murder had been committed. ${ }^{18}$ This shows that the judge, sheriff and local gentlemen were all involved in deciding where the body should be hung in chains. The following section will assess some of the most significant reasons for placing the gibbets of the Hawkhurst smugglers through an examination of the geography, landscape and context of the locations to determine what gibbet location says about the perception of the smugglers, their crimes and how they were to be presented to the public.

\section{London and the Generic Gibbet Location}

Gibbet locations in London followed a somewhat unique pattern to the rest of the country: rather than being selected for their proximity to the crime, gibbets were placed on frequently used roads or on common land. These 'gibbet areas' were generally located outside of London and were sites commonly associated with judicial punishment. The first of the Hawkhurst gang to be hung in chains were John Cook and Richard Ashcroft. The two men were tried at the Old Bailey for smuggling and executed on 29 July 1747. Cook and Ashcroft had both been ordered to give themselves up or face execution as part of the Offences against Customs or Excises Act of 1745. This Act named over 200 smugglers and gave them 40 days to hand themselves into the authorities, after which time they would be hanged if caught. A reward of $£ 500$ was offered for the apprehension of any of the smugglers. Cook and Ashcroft were the first to be hanged as part of this legislation and were eventually hung in chains in Shepherd's Bush, London. As the General Evening Post announced:

Yesterday morning about eight o'clock Richard Ashcraft [sic] and John Cook, the two smugglers, were carried under a strong detachment of the guards, from Newgate to Tyburn, and executed pursuant to their sentence; after which their bodies were hung on a gibbet at Shepherd's Bush, in the Acton Road, near James Hall, who was executed some time since for the murder of his master, Counsellor Penny. ${ }^{19}$

Shepherd's Bush (or Beggars Bush as it was sometimes known) was usually described as 'on the road to Acton', and no further description of the location was given. Historically the land was used by shepherds as pasture for their sheep on the way to Smithfield's market. The landmark that the bodies were placed near was another gibbeted body - that 
of James Hall, hanged for murder in 1741 . The gibbets were placed on a triangle of land on the main road west towards Oxford. Running north of Kensington Gardens and Hyde Park, this would have been a well-used road that enabled many to view the bodies on the way to and from the city. It was also three miles along the road to Tyburn and stood at the edge of London, making the bodies easily transportable from the place of execution to the site of the gibbet. As such, the location of their gibbeting was not significant in relation to their crime, and was of no significance to smuggling. There were, however, four other bodies hung in chains at this location between 1747 and 1751. One of these was another smuggler, Samuel Austin - his body was gibbeted in December 1747, a few months after Ashcroft and Cook. The Morning Advertiser reported that 'the body of Samuel Austin the smuggler, who was executed on Monday last at Tyburn, was afterwards hung in chains at Shepherd's Bush, on the same gibbet with the two lately executed' ${ }^{20}$ The significance of the spot was not related to the criminal or their crime, but instead that it was deemed to be a suitable area outside the capital on which bodies could be hung.

There were several locations in London that were used for gibbeting in this way, including Kennington Common and along the Edgware Road. Kennington Common was the location at which hangings occurred for those tried at the Surrey assizes. This large, open space associated with hangings would have been an ideal place to gibbet bodies. The Edgware Road ran north out of London from Tyburn, a key route for travellers and again associated with executions. Bodies were often hung in these places rather than near to where the crime was committed. Significantly, these places were near to where executions took place for the Sussex assize and at Tyburn respectively. Gill Smith was gibbeted on Kennington Common in 1738 following conviction for the murder of his wife. There were reports that Smith was to be hung in chains in St George's Fields, near to where he committed the murder. ${ }^{21}$ Smith was eventually hung in chains on the same gibbet on which John James and Jack Emerson had hung two years earlier. All three of these men had been hanged on Kennington Common, and in all likelihood this was the reason why they were gibbeted there. In 1735 Samuel Gregory was hung in chains on the Edgware Road in 1735. He was a member of Dick Turpin's gang and was convicted of robbery and rape. Gregory's body, like Gill Smith's, was hung on a pre-existing gibbet. He was hung alongside Joseph Rose, William Bush, Humphry Walker and John Field, other members of the Turpin gang. Placing bodies on pre-existing gibbets appears to have occurred only in the London area. 
Proximity to the gallows seems to have been a consideration in choosing these sites. Arthur Gray, perhaps the most notorious of all the midcentury smugglers, was hung in chains in 1748, on Stamford Common, another regular location for gibbets. Stamford Hill was, like Shepherd's Bush, located outside of the metropolitan boundary. Situated at Stoke Newington to the north of London, the gibbet was located on the Kingsland Road, a major northerly route from London. Significantly, both the roads through Shepherd's Bush and Stoke Newington were territories of highwaymen and associated with crime. In addition, both roads were used for the transportation of bodies into London for dissection. The placing of the gibbets at Shepherd's Bush and Stoke Newington therefore served to provide deterrence in an area associated with both crime and punishment. The General Evening Post stated that Gray's body was hung near Stamford Hill Turnpike, on the periphery of London. ${ }^{22}$ Gray's body was hung on a pre-existing gibbet, a double gibbet erected for Ferdinando Shrimpton and Robert Drummond in 1730. He was gibbeted next to the body of Samuel Hullock, a murderer who had been hung in chains on Stamford Hill in 1747. Reports from 1752 suggest that Grays's body was cut down from the gibbet in that year. Samuel Hullock's was reportedly also stolen from the gibbet. ${ }^{23}$

London therefore seems to be unique as gibbet locations followed a different pattern to elsewhere, focusing not on the relationship between the gibbet location, crime, criminal or victim, but in choosing sites associated with criminalised spaces, the gallows and post-mortem punishment itself. London had established sites of execution and gibbeting that were, unlike at other places, fixed: Execution Dock at Wapping was used for cases tried at the Admiralty Sessions, and until 1783 Tyburn staged the executions of those tried at the Old Bailey. As Simon Devereaux has shown, there were concerns over executions staged at Tyburn long before it was abolished; indeed there were frequent complaints made about the number of public punishments that were carried out in the heart of the city. ${ }^{24}$ Gibbeting in London reflected the wider use of the city as a stage on which punishments were carried out on regular basis. The 'gibbet areas' were selected for their proximity to the town, just outside the city boundaries and the fact that they were on a major travel route. This would allow for the maximum possible number of people to view the gibbet, without having it too near the city itself. It would have also meant that the bodies acted as a warning to highway robbers who frequented the roads. The gibbets of the smugglers in West Sussex applied some of the same principles, but were not concentrated in one particular area; furthermore there was no precedence for gibbeting bodies in the locality. 


\section{West Sussex and Prominent Locations}

The majority of the gibbets located in West Sussex were all erected for men convicted of murder at the Special Assizes held in Chichester in January 1749 . These offenders were all gibbeted in prominent locations surrounding Chichester, reflecting the outrage at the crimes committed and the desire to make an example of the smugglers. These Assizes were commissioned by the Duke of Richmond to try the men who had brutally tortured and murdered William Galley and Daniel Chater. The Galley and Chater murders have been well documented by both contemporaries and historians, and the crime is one of the most infamous cases of the period. ${ }^{25}$ As Table 3.1 shows, John Cobby, John Hammond, William Carter and Benjamin Tapner were all hung in chains after the Chichester Assizes. John Mills was also gibbeted in West Sussex for another horrific murder: he had whipped Richard Carswell to death in 1747. Mills was not apprehended at the time and efforts to capture him were heightened in the wake of the Galley and Chater murders. He was eventually tried in March 1749 at the Sussex Assizes. Mills was sentenced to be hanged and afterwards to be hung in chains, like four of the men tried at Chichester in January. Part of a smuggling family, his father and brother, Richard Mills senior and Richard Mills junior, were tried at the Special Assizes. Their gibbets were placed at prominent locations surrounding Chichester. ${ }^{26}$

Usually one of the key factors in selecting a gibbet location outside of the capital was proximity to the crime. ${ }^{27}$ However, none of these bodies were situated near any of the places associated with the murders, despite there being several locations at which the victims were tortured and the fact that the bodies were dumped in two different places. The locations associated with the crimes bore no relation to the places where the bodies were gibbeted. Galley and Chater were apprehended by members of the gang at the White Hart in Rowland's Castle, a village just over the Hampshire border. William Galley's body was found in a well in Lady Holt Park and Daniel Chater's body was buried in a fox hole in Coombe Hastings near Rake. Though it is not possible to discern the exact whereabouts of the places Galley and Chater were left, it is worth noting that the general locations would not have been suitable for hosting a gibbet as they are secluded. The only body placed near to a location significant to the crime was that of William Carter, who was gibbeted on the Portsmouth Road near Rake, fairly close to the Red Lion Inn where the men were tortured and Chater's burial place. Benjamin Tapner was ordered to be hung in chains at Rooks Hill (St Roches Hill) near Chichester, and John Cobby and John Hammond on Selsey Bill. 
These locations were selected as they were at prominent features in the local landscape in the area surrounding Chichester.

Though it has been known as the trundle for over 100 years, the 1726 county map of Sussex marks the hill as 'Rook's Hill'. Rooks Hill is a prominent location in West Sussex, now known as the trundle, a viewing point over Goodwood Racetrack. Given that the bodies were positioned at prominent locations in the county, the gibbeting of Benjamin Tapner there is logical. The high point of a natural hilly landscape, a body would have been visible for miles around. The exact location of the gibbet on the hill has not been recorded, though the spectacular view from the trundle across the county suggests how visible the gibbet would have been. The gibbet location here seems to have been based solely on the topography which allowed many to view the body and act as a warning to as many people as possible.

The Portsmouth Road, near Rake, where William Carter was gibbeted, is the road that runs north from Portsmouth, through Petersfield on to Liphook and eventually to London. This road was the main route from Portsmouth into London and would have sustained a high amount of traffic. The body would therefore have been viewed by travellers coming into the county. As at the trundle, the views from the road are farreaching and overlook much of the Sussex landscape. Again, the exact location of the gibbet cannot be ascertained, but views from the road near Rake are uniform. This gibbet location had the dual benefit of being on a road and at a high point in the landscape. As noted previously, Carter's was the only body to be placed near to a location associated with the crime; however, given that the other bodies were not situated close to any of the crime locations, it is probable that this was not the reasoning behind placing the gibbet of Carter there.

The bodies of John Hammond and John Cobby were placed on Selsey Bill to act as a warning to other smugglers. Their gibbet was designed to be visible to this specific group, not just to act as a deterrent to people in general, but to deter those whom Hammond and Cobby had worked alongside. Unlike the previous two gibbets, there are several sources that suggest where Cobby and Hammond were gibbeted. A 1778 county map marks the gibbet at the very edge of the bill, showing the spot with a small gibbet icon. A tithe map of 1830 , however, marks a 'gibbet field' further inland. It is not possible to narrow down where the exact location of the gibbet was, indeed it is likely that the coast has been eroded and the gibbet site has been lost to the sea. ${ }^{28} \mathrm{~A}$ blue plaque on Selesy Bill notes that 'as a warning to others the bodies of two smugglers executed in 1749 were hung in chains from the gibbet that stood 
in this field, much of which is now under the sea'. Unlike the previous rural locations, it is difficult to imagine the now built-up bill in the mideighteenth century. The uninterrupted views out to sea, however, give an idea of how the bodies would have been viewed by those on the surrounding seas. The fact that the gibbet was marked on maps indicates that it was considered a landmark, part of the fabric of the landscape.

The locations of the gibbets of the four murderers were all placed at prominent locations near Chichester and to act as a deterrent, and be viewed by as many people as possible. The exposed nature of the gibbets would also have enabled further sensory experiences of the gibbet: the squeaking and creaking as the body turned on the gibbet post and swung in the wind, and the smells of the decaying body. This would have allowed the gibbet to be experienced even when it was not visible. The bodies of Hammond and Cobby on Selsey Bill could be seen for miles along the coast and would act as a warning to smugglers, therefore also fulfilling the purpose of being gibbeted for a specific audience. The Galley and Chater murderers were hung in chains at carefully chosen locations to reinforce the image of justice. Like in London, the gibbets were located in the peripheries in places that many people could view them; however, unlike in London the gibbets would have been visible to other smugglers and people associated with the Hawkhurst gang. The location where the men were executed is marked by the smugglers' stone on the Broyle Road. The location of the gallows was a hill to the north of Chichester, again a site on the outskirts of the town. The weathered stone remains and is flanked by an information board that has a map showing the gibbet locations at Rake, Rooks Hill and Selsey Bill. It also details the original inscription on the stone:

Near this place was buried the body of William Jackson, a prescribed smuggler, who upon a special commission of Oyer and Terminer held at Chichester on the 16th day of January 1748-9 was, with William Carter, attained for the murder of William Galley, a custom house officer and who likewise was together with Benjamin Tapner, John Cobby, John Hammond, Richard Mills the elder and Richard Mills the younger, his son, attained for the murder of Daniel Chater. But dying in a few hours after sentence of death was pronounced upon him he thereby escaped the punishment which the heinousness of his complicated crimes deserved and which was the next day most justly inflicted upon his accomplices. As a memorial to posterity and a warning to this and succeeding generations this stone is erected A.D. 1749. 
The perpetrators of the Galley and Chater murders have thus retained their place in local history, and the reminder of the horrific crimes they committed still acts as a memorial to the men they killed and as a warning to others.

Although hung in West Sussex, the landscape of the places in which John Mills and Edmund Richards were gibbeted was very different to Rake, Rooks Hill and Selsey Bill. ${ }^{29}$ John Mills and Richards were also hung in chains for committing murder, though not at the same assizes as the other men. The locations of their gibbets were chosen for different reasons. Mills was hung and gibbeted at Slindon Common as this was where he came from while Richards was hung in chains on Hambrook Common for the same reason. Both men were transported long distances from the county gaol at Horsham in order to be executed and subsequently hung in chains near where they lived. According to the sheriff's craving, Mills was transported over 20 miles to the place of execution and Sheerman over 30 miles. Unlike the men tried at the Chichester assizes, these men were executed and gibbeted at the same place. Crime-scene executions were not common, and usually reserved for crimes for which a specific example needed to be set. ${ }^{30}$ It was, however, common for murderers to be hung in chains following a crimescene execution. Given that a gibbet post would have to be erected for the execution, the same post was used for hanging the body in chains. What is not clear is whether the bodies were executed at the scene of crime because they were due to be hung in chains, because there was a crime-scene hanging, or whether the two decisions were made independently of each other.

Slindon Common was a huge area in the mid-eighteenth century, so it is difficult to determine exactly where the gibbet would have been placed. The area of the common is comprised of very flat land in comparison to the contours of the previous locations. It is also likely that much of the area was wooded as maps from the period show a large area of woodland around Slindon. Hambrook Common retains the place name 'gibbet field' in a field along the West Ashling Road. Like Slindon, the area is flat and surrounded by hills. The gibbet was located in a field between Hambrook and the road from Portsmouth to Chichester, to the west of Cheesmans Lane. The positioning of the gibbets at the side of roads also shows that as well as putting the gibbet close to a significant place it was still important for the gibbet to be visible. This was usually the case when selecting a gibbet location, as more than one purpose was fulfilled.

Locating gibbets where the criminal came from or near to where the family lived was not uncommon in the eighteenth century - there 
were several gibbets removed as they caused distress to relatives who lived within sight of the gibbet. ${ }^{31}$ One such case was that of Richard Benstead. Hanged for murder in 1792, Benstead was ordered to be hung in chains on Lakenheath Common near where the crime had been committed. This was also near where his family lived. A few years after the gibbet had been erected his family were successful in getting the gibbet taken down. ${ }^{32}$ All of the smugglers who were convicted after the Special Assizes at Chichester and sentenced to hang in chains were gibbeted where they had lived or originated from. As noted above, John Mills was hung at Slindon Common and Edmund Richards at Hambrook Common. The other men were all gibbeted in East Sussex: Henry Sheerman at Rake; Richard Mapesden at Lewes; and George Chapman at Hurst Common. Thomas Kingsmill and William Fairall were both executed at Tyburn, but their bodies were sent to Goudhurst Gore and Horsmonden respectively.

\section{East Sussex and Local Connection}

Moving into East Sussex, the gibbets were concentrated in a smaller area than those in the west of the county. This is because they were all located near to where the criminals came from, the area surrounding Hawkhurst where the gang was centred. The gibbets of four smugglers were all located within ten miles of one another. Though the gibbets were close to one another, they were not close to where the men were executed. Unlike in West Sussex, none of these men were gibbeted near to their place of execution. All of the bodies travelled long distances to the site of the post-mortem punishment. William Hartnup was taken from Penenden Heath, and Thomas Kingsmill, William Fairall and Richard Mapesden from Tyburn. These were distances of fifteen miles for Hartnup from Penenden to Goudhurst and fifty miles for the other men from Tyburn to where they were hung in chains.

The only man convicted for the Galley/Chater murders and hung in chains in East Sussex was George Chapman, the other men were convicted of smuggling or robbing the custom house at Poole. William Hartnup was the first to be hung in chains in the area for 'being assembled in order to be aiding and carrying away unaccustomed goods'.$^{33}$ Hartnup was part of a group of smugglers who had terrorised the people of Goudhurst in the 1740s. The tensions between the villagers and locals finally came to a head when a group of local militia defeated the gang when they rode armed into the village. This became known as the Goudhurst Affray of 1747 and has been cited, somewhat inaccurately, as the defeat of the Hawkhurst gang. Hartnup was hung in 
chains on Goudhurst Gore the following year. The gore is shown on a contemporary map of the area, just to the north of Goudhurst, on the road leading to Horsmonden. Part of the gore can now be identified by Gore Lane, where houses now sit. Almost exactly a year after Hartnup was hung in chains there, Thomas Kingsmill's body was hung on the gore. Kingsmill had associations with Goudhurst; he was born there and like Hartnup he was involved in the affray of 1747 . It is possible that the bodies would have been there at the same time, though Hartnup's would have decomposed considerably by the time Kingsmill's was gibbeted. Although placed within the village, the gibbet was removed from the centre, at the village boundary, keeping the gibbets away from the space of the living.

William Fairall was hung in chains at Horsmonden, his gibbet has been immortalised in the street named 'Gibbet Lane'. Gibbet Lane follows a west-bound road out of the village and is near the village green and public house. Fairall was ordered to be hung in chains where he had lived, specifically on Horsmonden Green. Fairall was brought up in Horsmonden and according to accounts of his life he had been born to no trade and brought up smuggling. ${ }^{34}$ Unlike the gibbets at Goudhurst, this would have been in the centre of the village. This shows that gibbets were not always placed away from inhabited spaces, indeed bodies could often be viewed from people's houses. In London there were reports in the press that the body of highwayman John Haines was blown into somebody's private garden during a violent storm. ${ }^{35}$ It was alleged that upon hearing his sentence Fairall remarked to Richard Perrin, who was not sentenced to hang in chains and lamented the fate of his fellow smugglers, 'we [Fairall and Kingsmill] shall be hanging in the sweet air while you are rotting in your grave'. ${ }^{36}$ These remarks allegedly made by Fairall suggest that not all criminals viewed hanging in chains with the same horror as did William Jackson.

Richard Mapesden's gibbet was erected a few miles from Goudhurst at Lamberhurst. As with George Chapman's gibbet, the post was made at Lewes and transported to Lamberhurst as the carpenter would not make a gibbet for smugglers to be exposed on. ${ }^{37}$ Lamberhurst is a large village, and there is nothing to suggest where the gibbet would have been located. Much the same can be said for George Chapman's gibbet. Located at Hurst Green, Chapman's body was ordered to be hung in chains on the common. Both Lamberhurst and Hurst Green are now redeveloped, and there is no common, again making it difficult to determine exactly where the gibbet would have been located. The village does sit on the main route from Hastings, so it is probable that 
the gibbet was placed to be viewed by travellers using the road. Like the gibbet at Horsmonden these gibbets would have been much closer to residences than those in the west of the county.

The relationship between the town and the gibbet was therefore different in East Sussex to elsewhere, the space between the living and dead was closer and the dead were not so marginalised. As there is no record of who chose where the gibbets were to be located, there are a number of possibilities as to why this was the case. The men were ordered to be hung in chains at the judge's discretion; however, the sheriff and local magistrate also had a role in deciding the fate of the body, as with John Swan's body at Walthamstow. For example, the sheriff could choose which surgeon to give the body to when sentenced to dissection. The community could also put pressure on where the body would be placed, such as in Windsor in 1764 when the gibbeted body of Thomas Watkins was moved to a different location. Watkins had been executed in the Market Place in Windsor in March 1764, and his body gibbeted in Gallows Lane. Following complaints that the gibbet was a nuisance to passengers travelling along the adjacent road, in May the body was removed to the banks of the river. The body was evidently causing problems on local transport routes, leading to the body being relocated to a more suitable site. It is possible that the bodies in Sussex were placed in the local area to reclaim the land from the smugglers (as the people of Goudhurst did in the affray of 1747), and to act as a warning to those smuggling in the area or to act as an expression of public anger. Any or all of these could have been at the desire of the people of Goudhurst, the authorities acting to reflect real or perceived public opinion, or simply the wishes of the judge or sheriff. In Windsor, in the case of Thomas Watkins, the judge ordered the body to be hung in chains, but due to the body being deemed a nuisance by locals it was moved to a different location. In Walthamstow, the judge initially decided upon a location for the gibbet of John Swan, but subsequently decided the location was unsuitable and left the decision to the undersheriff and the gentlemen of the parish. The bodies of Joseph Guyant and Joseph Allpress were hung in chains on Finchley Common, but later the bodies were removed 'through the interest of Edward Allen Esq.' to a different spot on the same common. ${ }^{38}$ These cases show that there was some discussion as to where the body went, by those deemed to have an interest in the gibbet location and who held some authority in the area. Bodies may have been directed to a location by the judge initially, but if the location was not deemed suitable by locals, pressure could be applied for the selection of a new site for the gibbet. 


\section{The Gibbet Typography and its Wider Application}

This final section will consider how far the reasons used for selecting the gibbet locations of the smugglers in the 1740s and 1750s were applied more widely in the eighteenth century. Ultimately, it can be argued, proximity to the scene of the crime was the most significant factor in the choice of location, but there was also a variety of other factors considered that were dependent on the circumstances of the crime committed. The circumstances in Sussex in the 1740s led to gibbets of smugglers being placed either where the criminal came from, or at prominent locations in the county. There is a marked difference between the gibbet locations in the East and West of the county: in East Sussex the bodies were invariably hung in chains where the criminal was from, and in West Sussex gibbet locations were less to do with the associations that that specific place had than the fact they afforded a good vantage point for viewing the gibbets. In East Sussex the gibbets were concentrated in a small area around Hawkhurst; significantly the gibbets were placed in the area associated with smuggling and the Hawkhurst gang. Those criminals convicted of smuggling and robbing of the customs house at Poole were placed to act as a warning to those who lived in the area and were associated with the Hawkhurst gang. Gibbets in West Sussex were designed to be viewed by the largest possible number of people, placed at prominent locations around Chichester. These gibbetings for brutal murders were to act as an example to the populace as a whole, not just those associated with smuggling. Although there were different motivations behind the positioning of the gibbets, they were all designed to act as a very public deterrent, and were to be viewed by as many as possible.

The gibbets in both London and West Sussex were situated away from inhabited spaces, at prominent locations and along major travel routes, while in East Sussex the gibbets were positioned near to where local residents lived, reinforcing the purpose of the gibbet as being where the criminal came from. In general both of these practices were used when gibbeting bodies; however, bodies were generally gibbeted as close to the location in which the crime had taken place as possible. Newspapers and assize records provide evidence that in the 1740s over half of gibbet locations were selected for their proximity to the crime scene: this was the case for 27 per cent of sentences to hanging in chains. A further 28 per cent can be linked to the crime scene location, though it was not directly specified that this was the reason the location was selected. Aside from the reasons noted for the smugglers (topography, generic location, local connection) were a number of other explanations 
providing for the location of the gibbet: these were the location from which the victim came, the place the criminal was 'taken', and the proximity to the gallows on which the offender was hung. There were four bodies that cannot be linked to a crime scene, and for which no reason was given for the choice of gibbet location. ${ }^{39}$

The figures from the 1740s suggest that it was usual for gibbets to be placed near crime locations, except in London where suitable areas were selected for gibbets, such as in Shepherd's Bush or on the Edgware Road. This continued to be the case in London for the period in which the Murder Act was enforced. Numbers were smaller, however, and there were only 17 gibbets used between 1752 and 1834 to hang 21 offenders in chains. These gibbets were primarily situated on Finchley Common and Hounslow Heath. The first gibbet placed on Hounslow Heath was notably near to the location of the crime. Immediately prior to the enactment of the Murder Act, John Salisbury was sentenced to hang in chains there for mail robbery. This appears to have led to the site being used as a generic gibbet location in the mid- to late eighteenth century. The Edgware Road, Stamford Hill and Kennington Common were also used for gibbets as they had been prior to the Murder Act, though not as frequently as they had been in the 1730s and 1740 s.

In 49 per cent of the cases of hanging in chains in England and Wales between 1752 and 1834, the gibbet was noted as being situated 'near to where the crime was committed'. The exact positioning of the gibbet was dependent upon a number of factors, including where the gibbet would be most visible, where it would not be a nuisance to people, and the amount of traffic that would go past the gibbet. Whilst being near to the crime scene was the over-riding reason for choosing the area in which the gibbet would be placed, the exact positioning of the gibbet had to be practical. ${ }^{40}$ As in the 1740 s, there are a number of gibbets for which it has not been possible to find an exact location, or a reason for the selection of the gibbet location. At present, 5 per cent of the gibbet locations are unknown and in 32 per cent of the cases there has been no reason given for the selection of gibbet location. In all likelihood, many of these locations would have been near the crime scene. Given that in the 1740s, 27 per cent of places could be linked to the crime scene, it is probable that well over half of all gibbets during the Murder Act years were erected at a place close to where the crime was committed.

As in the 1740s, there were other reasons cited as the reason for selecting the gibbet location, and these were specific to the offender or the circumstances of the crime. John Clay, executed for the murder of his apprentice in 1783, was hung in chains on the common in his native 
town of Chilvers Coton, Warwickshire. Similarly, Roger Benstead from Suffolk was hung in chains on Undley Common, within view of the house in which he had lived. Benstead had shot one of his farm workers when he came to feed the cows. In March 1766 William Whittle was executed for murder. He was hung in chains at Cliff Lane Ends in Farington and the location was significant for more than one reason. This was 40 yards away from Whittle's father-in-law's house and 100 yards from his own house, on the road to Liverpool. Whittle was convicted of the murder of his wife and children, and had been ordered to be hung in chains near where the murder had been committed. Like in East Sussex, the gibbets were placed in inhabited areas, and the gibbets were in view of homes. Richard Benstead's gibbet was in fact removed a few years after it had been put up as a concession to Benstead's family, who lived near the gibbet. ${ }^{41}$ These gibbet locations all had links to the offender, but also the crime. This was different to the smugglers in East Sussex as the gibbet locations were selected because the offenders were from the area, but the crime for which the offender was hanged had not occurred there.

In Hampshire there were a number of offenders who were gibbeted on the coast in Portsmouth between 1766 and 1781; and these were men with naval connections. The first of these was Francis Arsine, a naval seaman who had murdered another seaman, Peter Varley, by stabbing him at 'the point' in Portsmouth in 1766. Arsine was ordered to be hung in chains at Blockhouse Point in Portsmouth dock. Two years later, James Williams was convicted for murder and ordered to be hanged at Southsea beach, Portsmouth and then gibbeted from the same post. He had been a sergeant of the marines, and at his execution 'the whole body of marines were drawn up close to the gibbet without arms for example'. ${ }^{42}$ In 1777 one of the most infamous criminals of the area was hung in chains at Blockhouse Point: James Hill, otherwise known as 'Jack the Painter'. Hill was convicted of arson following his attempt in 1776 to burn down the Portsmouth dockyard in protest against the American War. This spot became associated with 'Jack the Painter', and the disposal of bodies. In 1779 it was reported that a midshipman was executed on board the Culloden as a court martial for mutiny on the ship. Following his execution he was 'buried under the gibbet on which Jack the Painter hangs in chains'. ${ }^{43}$ In 1781 John Bryan was convicted of murder and hanged in Winchester, his body was subsequently hung in chains near to where James Hill had been gibbeted. Blockhouse Point in Portsmouth became a space associated with hanging in chains, and of the punishment of sailors. The connection with the sea and navy 
at Portsmouth docks meant that this location was used for a particular type of offender, much like the smugglers in the 1740s.

Mail robbers were a particular group of offenders who were subjected to hanging in chains with some frequency in the eighteenth century. There were 17 men hung in chains for mail robbery between 1752 and 1834 across the country, and attempts from the Postmaster General to gibbet more. These offenders were invariably hung in chains along the road where they had committed the robbery. In 1755 George Davies was convicted of robbing the Cirencester mail along the road from Beaconsfield to High Wycombe in Buckinghamshire. He was ordered to be hung in chains 'as near as was convenient' to the place where the crime was committed, which was an area notorious for highway robbery. ${ }^{44}$ Henry Lowndes (aka Clarke) was convicted for robbing the Warrington mail in 1791; it was reported that his prosecution cost thousands of pounds. ${ }^{45}$ Lowndes was gibbeted on the top of Helsby Tor, described as a lofty hill, 7 miles from Chester, allegedly on a gibbet 50 foot high. ${ }^{46}$ This location was selected for its topographical features, much like the gibbet on Rooks Hill, the gibbet would have been viewed by many thanks to its location. The gibbet did not remain in situ for very long, however, for soon after the gibbet was erected it was cut down and not replaced. Offenders convicted of highway robbery were treated in a similar way to mail robbers, and although those convicted or either highway robbery or mail robbery were not bound by law to receive a post-mortem punishment as murderers were, hanging the body in chains along the road where the crime had been committed was believed to deter others from committing such crimes.

For the smugglers in the 1740s, hung in chains over a short period of time, the reasons behind the selection of gibbet locations were temporally and spatially specific. In certain circumstances, other offenders were also gibbeted in locations deemed suitable, such as when seamen were gibbeted in Portsmouth docks. In general, however, gibbet locations were selected for their proximity to the crime location, coupled with practicality in positioning the gibbet by a road on suitable land. The positioning of the gibbets of the smugglers was therefore not typical, but neither were the crimes or the circumstances of their hanging in chains. They became a specific target of the government, and a special example was to be made of them. Those gibbets in West Sussex were designed to make the bodies viewable to as many people as possible, a reminder of the shocking murders committed. This was reinforced by the erection of the smugglers stone at Broyle, a reminder of where the men were executed. Those in East Sussex were gibbeted at locations 
with Hawkhurst at the centre. These were to act as a warning to those close to the smugglers and the community in which the smugglers operated. The Hawkhurst smugglers therefore provide a unique insight into the processes of punishment, showing that even an extreme punishment could be adapted to fit particular circumstances.

\section{Acknowledgement}

The author would like to acknowledge that this chapter forms part of a wider research project, 'Harnessing the Power of the Criminal Corpse', which is generously funded and made available open access by the Wellcome Trust (grant number 095904/Z/11/Z).

\section{Notes}

1. Figures compiled from the Sheriffs' Cravings: The National Archives, London, UK (hereafter TNA), Sheriffs' Cravings, T 64/262; TNA, Sussex and Kent Assizes files, ASSI 23/6, ASSI 31/2; The Proceedings of the Old Bailey, 1674-1913 (hereafter Old Bailey Online), http://www.oldbaileyonline.org/ (accessed 29 May 2014).

2. Figures from the 'Harnessing the Power of the Criminal Corpse' database, 1752-1834. The data was compiled from a variety of sources, including newspapers and periodicals, and Assize Records (ASSI) at TNA. The most significant source of information was the Sheriffs' Cravings (T 90 and T 64) at TNA.

3. Z. Dyndor, 'The Government and the Gibbet: Fighting the War on Smuggling in Eighteenth-Century Sussex' (unpublished research paper).

4. N. Rogers, Mayhem: Post-War Crime and Violence in Britain, 1748-1753 (New Haven, 2003), p. 120.

5. See the sources cited in note 1 .

6. There were three men hung in chains in Suffolk and Norfolk between 1748 and 1750: TNA, ASSI 33/2.

7. TNA, Chichester Special Commission, KB 8/72.

8. The Duke of Richmond's files relating to this can be found in West Sussex Record Office (hereafter WSRO), Goodwood MSS 155; TNA, Chichester Special Commission, KB 8/72.

9. 'Gentleman at Chichester', Smuggling and Smugglers in Sussex: a Genuine History of the Unparalleled Murders of Mr William Galley and Daniel Chater (Brighton, 1749).

10. Ibid.

11. Sarah Tarlow, 'The Technology of the Gibbet', International Journal of Historical Archaeology (forthcoming). I am very grateful to Professor Tarlow for providing me with a manuscript copy of her article.

12. TNA, Sheriffs' Cravings, T 64/262.

13. TNA, Sheriffs' Cravings, T 64/262.

14. Figures from the 'Harnessing the Power of the Criminal Corpse' database (see note 2). 
15. N. Whyte, 'The Deviant Dead in the Norfolk Landscape', Landscapes 4 (2003), 24-39.

16. Sarah Tarlow and Zoe Dyndor, 'The Landscape of the Gibbet', Landscape History (forthcoming).

17. General Advertiser, 5 May 1752.4

18. Covent-Garden Journal, 1752, Issue 27; Read's Weekly Journal or British Gazetteer, 9 May 1752.

19. General Evening Post, 28 July 1747.

20. Penny London Post or the Morning Advertiser, 23 December 1747.

21. Weekly Miscellany, 31 March 1738.

22. General Evening Post, 28 May 1748.

23. General Evening Post, 10 May 1748.

24. G. Smith, 'Violent Crime and the Public Weal in England, 1700-1900', in Richard McMahon (ed.), Crime, Law and Popular Culture in Europe, 1500-1900 (Cullompton, 2008), pp. 190-218; S. Devereaux, 'Recasting the Theatre of Execution: the Abolition of the Tyburn Ritual', Past and Present 202 (2009), 127-74.

25. Rogers, Mayhem; F. F. Nichols, Honest Thieves (Birkenhead, 1973); F. Mclynn, Crime and Punishment in Eighteenth-Century England, (Oxford, 1989); C. McCooey, Smuggling on the South Coast (Stroud, 2012); J. Rule, 'Social Crime in the Rural South in the Eighteenth and Nineteenth Centuries', in J. Rule and R. Wells (eds), Crime, Protest and Popular Politics in Southern England 1740-1850 (London, 1997), pp. 135-53; Cal Winslow, 'Sussex Smugglers', in Douglas Hay et al. (eds), Albion's Fatal Tree (New York, 1975), pp. 119-66.

26. Locations of gibbets are referred to by the Duke of Richmond: WSRO, Goodwood MSS 155/ H132.

27. Tarlow and Dyndor, 'The Landscape of the Gibbet'.

28. Thomas Yeakell and William Gardner, Sussex Great Survey Map (1778), WSRO, $\mathrm{PM} / 48$. The 1778 county map as annotated by Cavis-Brown in 1906 indicates that the coastline had changed and that the gibbet was now under sea level.

29. Richard Budgen's map of West Sussex (1724), showing Rake, Rook's Hill, Slindon Common, Hambrook Common and Selsey Bill, the gibbet locations of members of the Hawkhurst gang, WSRO, PM/608.

30. See the chapter by Steve Poole in this volume.

31. Tarlow and Dyndor, 'The Landscape of the Gibbet'.

32. The Morning Post, 19 October 1824.

33. TNA, Lent Assizes for Kent 1747/8, Home Circuit Gaol books, ASSI 31/2.

34. The Ordinary of Newgate's Account of the Behaviour, Confession, and Dying Words of the Nine Malefactors Who were executed at Tyburn on Wednesday the 26th of April 1749.

35. Morning Chronicle, 19 March 1799.

36. The Malefactor's Register; or, the Newgate and Tyburn Calendar (London, 1779), p. 221.

37. TNA, Sheriffs' Cravings, T 64/262.

38. Middlesex Journal or Universal Evening Post, 14-16 July 1772.

39. Of 60 gibbet locations selected in the 1740s, reasons given for the selection were as follows: 16 where the crime was committed; 7 in a London 'gibbet area' (5 of these were smugglers); 7 where the criminal was from ( 6 of these 
smugglers); 4 for the topography (all smugglers); 3 by the gallows; 1 where the victim was from; 1 where the criminal was taken. The remaining 21 had no reason given, although 17 of these can be linked to the place of crime.

40. The various factors that went into choosing the exact site of the gibbet are discussed in more detail in Tarlow and Dyndor, "The Landscape of the Gibbet'.

41. The Morning Post, 19 October 1824.

42. Public Advertiser, 1 August 1768.

43. General Evening Post, 22 June 1799.

44. Whitehall Evening Post or London Intelligencer, 2 March 1755.

45. Diary or Woodfall's Register, 3 May 1791; J. Hemmingway, History of the City of Chester (Chester, 1831), vol. 2, p. 297.

46. Diary or Woodfall's Register, 3 May 1791.

Except where otherwise noted, this chapter is licensed under a Creative Commons Attribution 4.0 International License. To view a copy of this license, visit http:// creativecommons.org/ licenses/by/4.0/ 